\title{
"The mediating role of growth opportunity in good corporate governance-stock return relationship"
}

\begin{tabular}{ll} 
AUTHORS & $\begin{array}{l}\text { Rakha Wardhana } \\
\text { Bambang Tjahjadi } \\
\text { Yani Permatasari } \\
\text { Rakha Wardhana, Bambang Tjahjadi and Yani Permatasari (2017). The } \\
\text { mediating role of growth opportunity in good corporate governance-stock return } \\
\text { relationship. Investment Management and Financial Innovations, 14(3), 313-321. } \\
\text { doi:10.21511/imfi.14(3-2).2017.02 }\end{array}$ \\
\hline ARTICLE INFO & http://dx.doi.org/10.21511/imfi.14(3-2).2017.02 \\
\hline DOI & Thursday, 23 November 2017 \\
\hline RELEASED ON & Monday, 26 June 2017 \\
\hline RECEIVED ON & Friday, 13 October 2017 \\
\hline ACCEPTED ON & $\begin{array}{l}\text { (co) EY-Nc } \\
\text { This work is licensed under a Creative Commons Attribution-NonCommercial } 4.0 \\
\text { International License }\end{array}$ \\
\hline LICENSE & "Investment Management and Financial Innovations" \\
\hline JOURNAL & $1810-4967$ \\
\hline ISSN PRINT & $1812-9358$ \\
\hline ISSN ONLINE & LLC "Consulting Publishing Company "Business Perspectives" \\
\hline PUBLISHER & LLC "Consulting Publishing Company "Business Perspectives" \\
\hline FOUNDER &
\end{tabular}

NUMBER OF REFERENCES

37

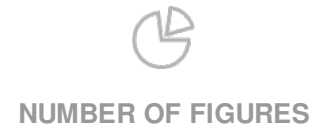

3
NUMBER OF TABLES

4

(C) The author(s) 2023. This publication is an open access article. 


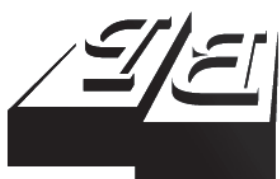

BUSINESS PERSPECTIVES

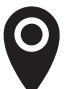

LLC "CPC "Business Perspectives" Hryhorii Skovoroda lane, 10, Sumy, 40022, Ukraine

www.businessperspectives.org

Received on: $26^{\text {th }}$ of June, 2017 Accepted on: $13^{\text {th }}$ of October, 2017

(C) Rakha Wardhana, Bambang Tjahjadi, Yani Permatasari, 2017

Rakha Wardhana, Faculty of Economics and Business, Universitas Airlangga, Indonesia.

Bambang Tjahjadi, Faculty of Economics and Business, Universitas Airlangga, Indonesia.

Yani Permatasari, Faculty of Economics and Business, Universitas Airlangga, Indonesia.

\section{(ㄷ)(1) $(8)$}

This is an Open Access article, distributed under the terms of the Creative Commons Attribution-NonCommercial 4.0 International license, which permits re-use, distribution, and reproduction, provided the materials aren't used for commercial purposes and the original work is properly cited.
Rakha Wardhana (Indonesia), Bambang Tjahjadi (Indonesia),

Yani Permatasari (Indonesia)

\section{THE MEDIATING ROLE OF GROWTH OPPORTUNITY IN GOOD CORPORATE GOVERNANCE-STOCK RETURN RELATIONSHIP}

\begin{abstract}
Improving the welfare of its owner or shareholder and maximize shareholder value through increased firm's value should be one of the goals in establishing a company. Consequently, it becomes essential for the company to continue to increase its value in order to retain the trust of its shareholders, for instance by conducting good corporate governance (GCG). On the other hand, from the owner's point of view, it is important to not only evaluate the corporate governance, but also to take a look at firm's growth opportunity, because it basically reflects the management's productivity. Studies related to the influence of corporate governance on stock return have been extensively done before. Similarly, this research is related to the influence of growth opportunity on stock return. However, it is still difficult to find studies that combine these three variables, therefore this study aims to know the influence of good corporate governance on stock return directly and indirectly through firm's growth opportunity by using sample data of 92 observation Corporate Governance Perception index lists in Indonesia Stock Exchange for 2010-2014. The analysis method of this research is the quantitative approach by hypothesis testing through path analysis performed with SmartPLS 3.0. The direct hypothesis result showed that: (1) good corporate governance did not have a significant influence on firm's growth opportunity while; (2) it also had a negative influence and did not have a significant influence on stock return, and (3) firm's growth opportunity had a significant influence on stocks return. However, the in direct hypothesis result showed that firm's growth opportunity could not mediate the relationship between good corporate governance and stock return.
\end{abstract}

Keywords corporate governance, stock returns, growth opportunity

\section{JEL Classification G30}

\section{INTRODUCTION}

One of the goals in establishing a company is not only to improve the welfare of its shareholder, but also to maximize shareholder's value through increased firm's value which is reflected in its stock price. The higher stock price volatility shows the decrease of investor confidence in the results of firm's performance. Therefore, it becomes essential for the company to continue to increase its value in order to retain the trust of its shareholders, for instance by implementing good corporate governance (GCG) (Brigham \& Houston, 2001; Huang, 2010). Companies should implement GCG principles, which include transparency, accountability, independence, responsibility, and fairness, in order to create good corporate governance. With the implementation of GCG, the decision-making process will take place better so that it 
will create optimal decisions, improve the efficiency of operational performance, and create an excellent work culture such as working effectively and efficiently so as to decrease the cost of capital and able to minimize risk, it can also increase investor confidence to save their funds in the form of company shares, hence, the volatility of stock prices may decrease (Huang, 2010; KNKG, 2006; Maksum, 2005; Jensen \& Meckling, 1976; Koerniadi, 2014).

Eduardus (2010) asserted that investors as the shareholders of the company certainly expect high returns in the future as the result obtained from investments they have made. Thus, in order to evaluate the stock returns, investors need to not only evaluate company's performance in terms of corporate governance, but also by take a look at the company's growth opportunity which is basically a reflection of the productivity of the company and is a desired achievement of the internal company (management), as well as external parties (investors and creditors). High growth opportunities will give company a higher earning opportunity in the future. This will certainly give a positive effect on stock returns (Mas'ud, 2008). Companies which have high growth opportunities generally require external funds to expand, thus encouraging companies to make improvements in the implementation of corporate governance in order to lower the cost of capital (Darmawati et al., 2004).

Although there are still many inconsistent results, research related to the influence of corporate governance on stock return has been done extensively before. Similarly, the research is related to the influence of growth opportunity on stock return. However, it is still difficult to find studies that combine these three variables. Therefore, it is interesting to not only see whether the implementation of corporate governance and firm's growth opportunity affect the stock return, but also the relationship between the two variables, and also see whether the actual growth opportunity mediates the influence of corporate governance on stock returns.

\section{LITERATURE REVIEW}

\subsection{Agency theory}

Jensen and Meckling (1976) defined agency relationship as a contract where one or more principals assigned other party (agent) to perform service in the name of principals with delegating authority of decision-making to agent. In this case, the principals are shareholders and/or investors, while agents are management or corporate manager. Yet, on the other hand, agency theory perspective stated that there is a segregation between firm owner and firm manager that will cause information asymmetry between manager as agent and firm owner as principal. Manager will tend to act for his own interest instead of shareholder interest. The information asymmetry can be minimized by implementing GCG. With the implementation of GCG, the decision-making process will take place better so that it will create optimal decisions and thus increase the shareholder trusts (Huang, 2010).

\subsection{Good corporate governance and stock return}

A good corporate governance system will provide effective protection to shareholders and creditors to get back on their investment as reasonably, appropriately, and efficiently as possible, and ensure that management is performing the best as they can for the company's interests. Huang (2010) asserted that stock price fluctuations are closely related to the decrease of investor confidence in the results of corporate performance and weak corporate governance. Stock price volatility will certainly affect the stock return. This is in line with Rostami (2016) who examined the effects of corporate governance components on listed companies in Tehran Stock Exchange where the results indicate a positive relationship between the components of good corporate governance on stock returns. Morey et al. (2009) also found that there is an abnormal return around the date of the an- 
nouncement of corporate governance information on emerging market countries that have the similar capital market efficiency to Indonesia where results indicate significant corporate governance impact on stock returns. However, several other studies have shown contradictory results that good corporate governance variables have no effect on stock returns in Asia and elsewhere (Budiharjo, 2016; Toudas \& Bellas, 2014; Kouwenberg et al., 2012). Therefore, this study proposes the following:

\section{H1: Firm's good corporate governance positively} influences stock return.

\subsection{Good corporate governance and growth opportunity}

Himmelberg et al. (2002) asserted that investor protection will increase the willingness of investors to provide funding for the company and this is reflected in lower costs and the availability of larger external funding. This indicates that companies which need large funding in the future will benefit greatly from the implementation of good corporate governance at this time. In addition, great growth opportunity companies will need to raise larger external funding for expansion and therefore require improvement on good corporate governance mechanisms as a form of a better protection to minority shareholders and then will tend to lower their capital costs. Therefore, this study proposes the following:

H2: Firm's good corporate governance positively influences firm's growth opportunity.

\subsection{Growth opportunity and stocks return}

Growth is the impact of the flow of corporate funds from operational changes caused by growth or decrease in business volume, it is a growth opportunity for a company in the future (Mai, 2006). Company growth can be realized by using the investment as efficient as possible.
The growth indicator used is asset growth or total assets used for the company's operational activities (Amalia, 2011). Although Anggrahini (2016) and Quynh-Nhu (2009) asserted that growth opportunity has no significant influence on stock return, yet companies that have rapid growth often have to increase their fixed assets, therefore the growth of high assets will increase the return. High growth companies choose to use stocks to mark the company's operations, while companies with low growth opportunities will choose to use long-term debt (Hemuningsih, 2013). Moreover, high growth opportunities will give company a higher earning opportunity in the future. This will certainly have a positive effect on stock returns (Mas'ud, 2008). Therefore, this study proposes the following:

H3: Firm's growth opportunity positively influences stock return.

\subsection{The mediating effect of growth opportunity}

High growth opportunities will give you a higher earning opportunity in the future. This will certainly give a positive effect on stock returns. Firms with high growth opportunities generally require external funds to expand, so there is a need for improvements in the implementation of corporate governance undertaken by firms in order to reduce the cost of capital (La Porta et al., 1999; Klapper \& Love, 2002) in Wardani (2008). Companies that have the ability to grow or invest will be more profitable, which will ultimately affect the good performance of the company. The need for external funding is significantly related to good corporate governance indicators. This result provides support for the hypothesis that a growing company with a great need for external financing has more incentives to adopt good corporate governance practices (Durnev \& Kim, 2005). Therefore, this study proposes the following:

H4: Firm's growth opportunity mediates the relationship between good corporate governance and stocks return. 


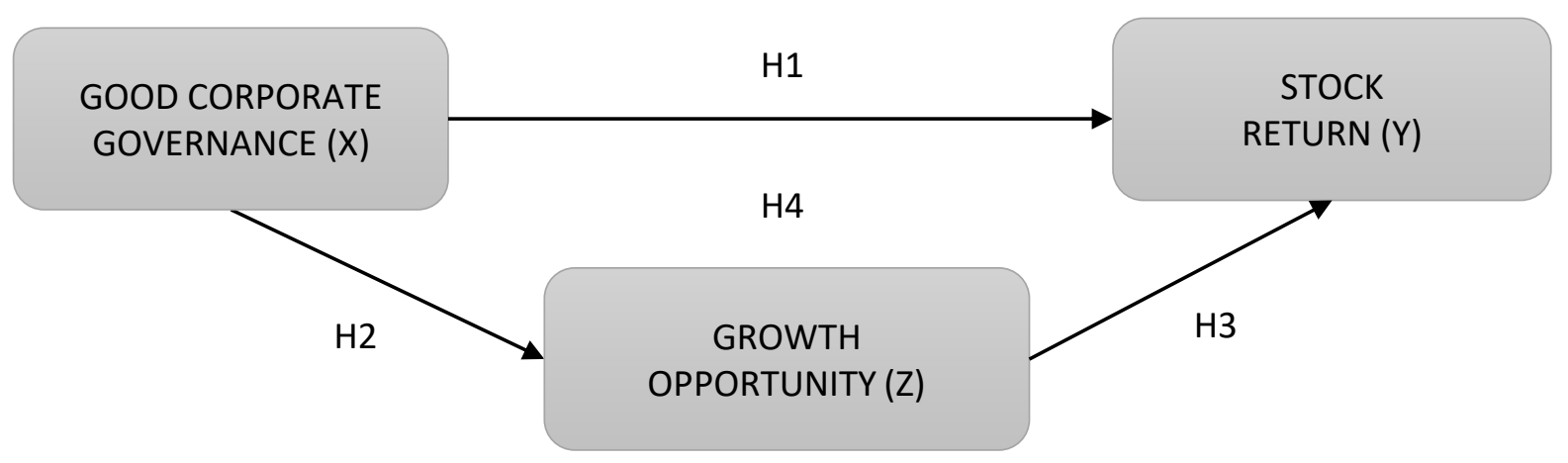

Figure 1. Research model

\section{RESEARCH METHODOLOGY}

The relationship among variables in this study is presented in a research model in Figure 1.

\subsection{Operational definitions and measurement}

\subsubsection{Good corporate governance $(X)$}

The value of the corporate governance of each company can be seen in the Corporate Growth Perception Index (CGPI), which is the rating of the implementation of corporate governance reported by The Indonesian Institute for Corporate Governance (IICG) in cooperation with SWA Magazine to determine corporate ranking in the use of corporate governance in Indonesia. CGPI score starts from 0 to 100 . If the company has a score close to or reach a value of 100 , indicating that the company is getting better in implementing corporate governance.

\subsubsection{Growth opportunity (Z)}

Growth opportunity is a future company's growth opportunity (Mai, 2006). Companies that have rapid growth often have to increase their fixed assets. Another definition of growth opportunities is the change in total assets owned by the company (Kartini \& Arianto, 2008). The indicator used in this study is asset growth which means is a representation of the increase or decrease (growth) of assets every year. Systematically asset growth can be formulated according to Mas'ud (2008, p. 83) as follows:

$$
\begin{aligned}
& \text { Growth opportunity }= \\
& =\frac{\text { Total asset }+1-\text { Total year } t}{\text { Total year } t} .
\end{aligned}
$$

\subsubsection{Stock return $(Y)$}

Return is the result obtained from the investment (Fidhayatin \& Dewi, 2012, p. 205). The sources of stock returns consist of two main components: dividend yield and capital gain (loss). This study calculates the stock return by using capital gain (loss), i.e., the current stock price is reduced by the stock price of the previous period compared to the previous period stock price. According to Jogiyanto (2000), the formula to calculate the stock return is as follows:

$$
R_{i t}=\frac{P_{t}-P_{t-1}}{P_{t-1}},
$$

where $P_{t}$ - stock price in $t$ period, $P_{t-1}-$ stock price in $t-1$ period.

The return of the company stock is measured by using the value of closing price in the related year. The dividend component is not included in the calculation, because it has the potential to cause an outlier, and is done on the grounds to be able to know the actual stock price changes.

\subsection{Research design and data collection procedure}

The type of data used in this study is secondary data from companies listed on the Indonesia Stock Exchange (BEI) which are included in the rating of Corporate Governance Perception 


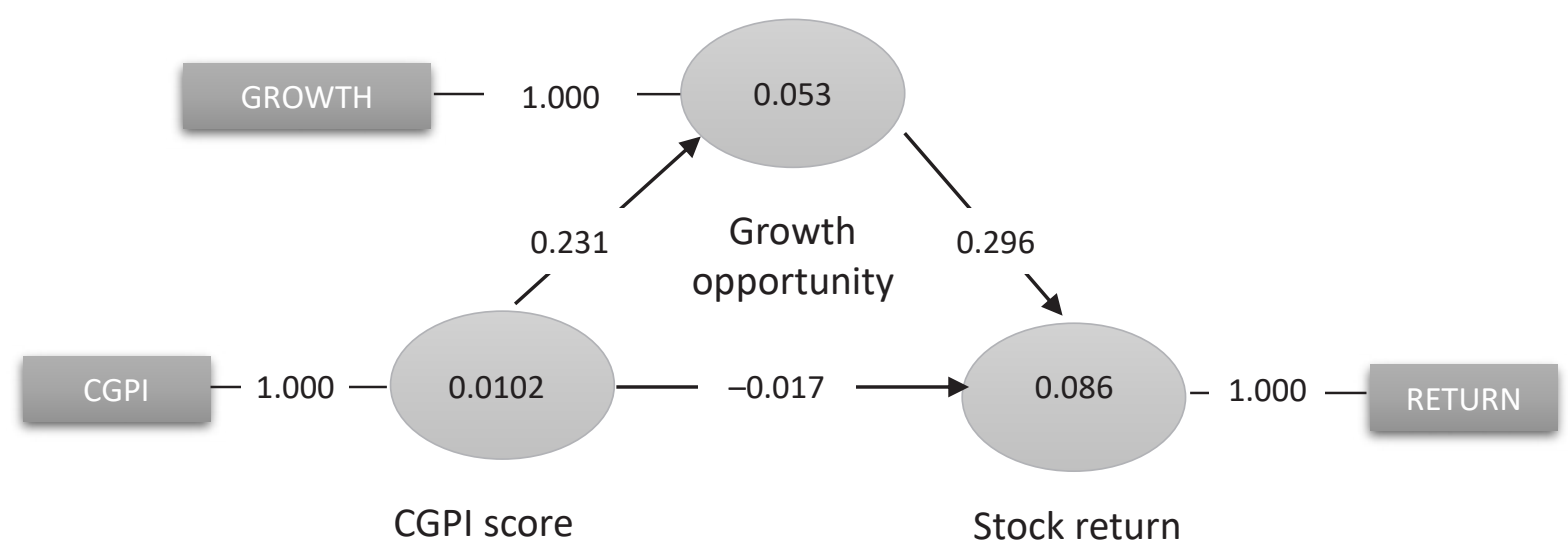

Figure 2. Algorithm of outer output model

Index (CGPI) by The Indonesian Institute for Corporate Governance (IICG) and CGPI ranking report for the period 2010-2014. The closing stock price data are obtained from yahoo finance. Sources of data used in this study were obtained from the Indonesia Stock Exchange (BEI) website www.idx.co.id and the IICG report from the www.iicg.org website. Secondary data were collected using archive data collection techniques. These secondary data include audited financial statements on the Indonesia Stock Exchange website, the results of corporate governance assessment by IICG published by SWA magazine, as well as stock price data at year-end closing on the Yahoo finance website to assist in the selection of company samples.

The research hypotheses will be tested quantitatively by using SmartPLS v. 3.0. (Partial Least
Square) software and by path analysis. It is more commonly used and suitable for social research thus it is used in this study.

\section{RESULT AND DISCUSSION}

The result of conformity evaluation of conceptual model in Figure 2 shows that all variables in this study have loading factor value 1.00 . This is because each variable in this study has only one indicator. Therefore, in this study, there is no indicator that needs to be dropped.

Table 1. Loading factor value

\begin{tabular}{l|c:c:c}
\hline Indicator & $\begin{array}{c}\text { Growth } \\
\text { opportunity }\end{array}$ & $\begin{array}{c}\text { Stock } \\
\text { return }\end{array}$ & $\begin{array}{c}\text { CGPI } \\
\text { score }\end{array}$ \\
\hline CGPI & - & - & 1.00 \\
\hdashline GROWTH & 1.00 & - & - \\
\hdashline RETURN & - & 1.00 & - \\
\hline
\end{tabular}

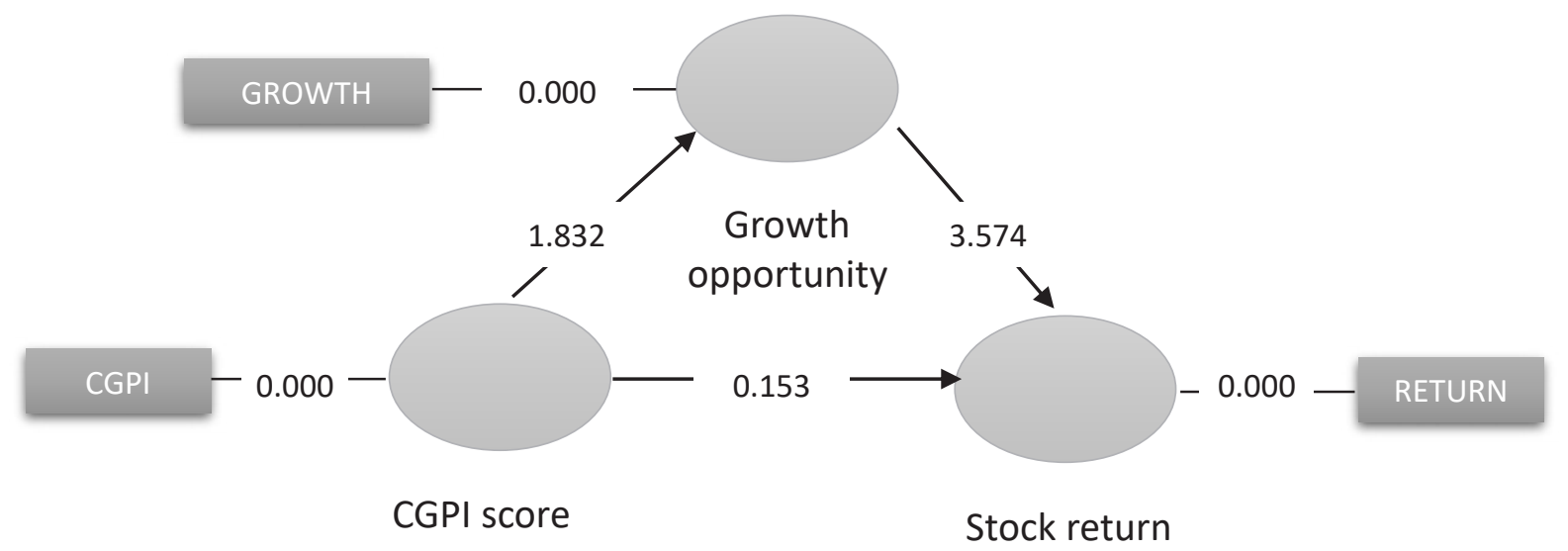

Figure 3. Bootstrapping output result 


\subsection{Hypotheses testing result}

\subsubsection{Inner model PLS testing}

Table 2 and Figure 3 show that there are three paths available and only one path in the model has a significant effect. The coefficient value of the path marked positive on the original sample $(\mathrm{O})$ shows the relationship of these variables is linear or proportional. The coefficient value of the path marked negatively indicates the relationship of the variable is opposite.

Table 2. Inner model PLS testing result

\begin{tabular}{|c|c|c|c|c|c|}
\hline Path & 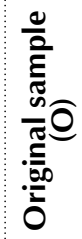 & 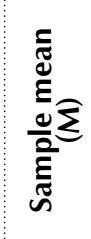 & 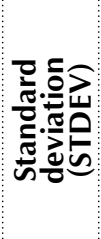 & 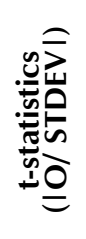 & $\frac{\mathscr{d}}{\frac{d}{2}}$ \\
\hline $\begin{array}{l}\text { Growth opportunity } \rightarrow \\
\rightarrow \text { Stock return }\end{array}$ & 0.30 & 0.30 & 0.08 & $3.57^{*}$ & 0.00 \\
\hline $\begin{array}{l}\text { CGPI score } \rightarrow \\
\rightarrow \text { Growth opportunity }\end{array}$ & 0.23 & 0.23 & 0.13 & 1.83 & 0.07 \\
\hline $\begin{array}{l}\text { CGPI score } \rightarrow \\
\rightarrow \text { Stock return }\end{array}$ & -0.02 & -0.02 & 0.11 & 0.15 & 0.88 \\
\hline
\end{tabular}

\subsubsection{Mediating effect testing}

Tables 3 and 4 below showed the indirect influence of good corporate governance on stock return through firm's growth opportunity.

Table 3. Indirect influence testing

\begin{tabular}{|c|c|c|c|c|}
\hline Hypothesis & 휴흘 & 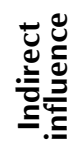 & 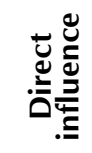 & 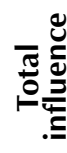 \\
\hline $\mathrm{H} 1$ & $X \rightarrow Z \rightarrow Y$ & 0.07 & -0.02 & 0.05 \\
\hline
\end{tabular}

Table 4. P-values of indirect influence result

\begin{tabular}{|c|c|c|c|c|c|}
\hline Path & 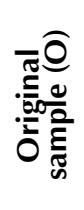 & 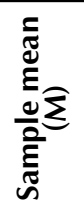 & 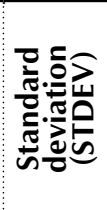 & 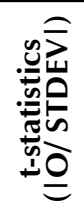 & $\frac{\mathscr{E}}{\frac{1}{2}}$ \\
\hline $\begin{array}{l}\text { CGPI score } \rightarrow \\
\rightarrow \text { Stock return }\end{array}$ & 0.07 & 0.07 & 0.05 & 1.46 & 0.14 \\
\hline
\end{tabular}

\section{DISCUSSION}

\subsection{The influence of firm's good corporate governance on stock return}

Hypothesis 1 (H1) stated that the firm's good corporate governance positively influences stock return. However, this study showed different results with the hypothesis 1 . The influence of good cori porate governance on stock return has an original sample of -0.02 , meaning that the more companies apply good corporate governance, the lower return of stocks obtained by the company. The influence is not large enough, because the significance from the $t$-statistics is $0.15<1.96$ so the path is not significant, hence, hypothesis 1 (H1) is rejected. The results of this study are in line with research conducted by Bauer et al. (2004) indicating that there is no significant influence on good corporate governance and stock return. The negative results of this study are also in line with Sugiyanto (2010) who states that in large companies, GCG has a negative and not significant effect on stock returns. This is because the negative effect on large companies is caused by institutional ownership as a GCG measurement tool. Investors of this institution generally consist of holding companies that are affiliated (Sugeng, 2010). Therefore, the public responds negatively to that matter. The CGPI assessment conducted by IICG is not merely a benchmark for investors to provide external financing for the company, because the program is voluntary. By its voluntary nature, it cannot be ascertained whether all good companies have followed the assessment so that CGPI scores have no effect on investors' decisions to invest.

\subsection{The influence of firm's good corporate governance on firm's growth opportunity}

Hypothesis 2 (H2) stated that the firm's good corporate governance positively influence the firm's growth opportunity. The influence of good corporate governance to growth opportunity has an original sample of 0.23 means that the company has better corporate governance, the better the growth opportunity of the company. However, the effect is not large enough, because the signifi- 
cance is seen from the $t$-statistics of $1.83<1.96$ so the path is not significant, so the hypothesis 2 (H2) of this study is rejected. This study is in line with Webb (2006) and Khanchel (2007) who shows that growth opportunity is not influenced by good corporate governance. This is because the implementation of good corporate governance is more long-term and is expected to also provide benefits in the long term so that the response to the implementation of corporate governance itself will be difficult to measure if in the short term. The lack of consistency of the company's participation in this survey each year, this is demonstrated during the observation year (2010-2014) many inconsistent corporate samples participate consecutively each year. This allows for a lack of clarity of the apparent tendency or low influence of CGPI on growth.

\section{OPPORTUNITY}

\subsection{The influence of firm's growth opportunity on stock return}

Hypothesis $3(H 3)$ stated that the growth opportunity of the company affects the stock return. The influence of growth opportunity on stock return has an original sample of 0.3 , it means that the better growth opportunity of the company the higher the return of stock received. The significance of GCG to corporate growth opportunity is seen from the $t$-statistics of 3.57 , since $t$-statistics $>1.96$ then the pathway is significant, so the hypothesis 3 (H3) of this study is accepted. This research is in line with the research of Agustina (2007) and Quynh-Nhu (2009) where growth opportunity has a significant effect on abnormal return. The results of this study in line with the pattern of thinking researchers, i.e. companies that have increased fixed assets means the company has a good opportunity to grow, because there is an investment in fixed assets productive and if the company has a chance to grow then the company will have the ability to bring profits so that the company will increase investor confidence to invest and then will give a bigger stock return.

\subsection{The influence of good corporate governance on stock return through firm's growth opportunity}

Hypothesis 4 (H4) stated that the firm's growth opportunity mediates the influence of good corporate governance on stock returns. The amount of influence of good corporate governance to growth opportunity is 0.23 where the value of significance of good corporate governance on growth opportunity of the company seen from $t$-statistics of 1.83 , because the value of $t$-statistics $<1.96$ then the path is not significant. However, the influence of firm's growth opportunity on the stock return is 0.03 with the significance seen from the $t$-statistics of 3.57 and greater than 1.96 so the path is significant. In determining whether the growth opportunity variable mediates the good corporate governance relationship on stock return, a significant relationship between the variables is required. Thus, the hypothesis 4 (H4) is rejected. The results of this study indicate that the implementation of good corporate governance will not bring significant influence to the level of growth opportunity of the company. This implies that companies which followed the survey are not necessarily companies that have good operating performance that ultimately affects the growth opportunity, because the survey is also followed voluntarily. In addition, the magnitude of the firm's growth opportunity rate is likely to be largely due to factors influencing the growth opportunity. Factors other than good corporate governance implementation, such as good skills owned by labor and company management in managing its assets and macroeconomic conditions such as rupiah exchange rate and interest rate should be considered.

\section{CONCLUSION}

Several conclusions can be drawn based on the result of this study. First of all, good corporate governance has an insignificant influence on stock return. This is mainly due to the voluntary nature of CGPI assesstment. It cannot be ascertained whether all good companies have followed the assessment so that 
CGPI scores have no effect on investors' decisions to invest. Second, this study revealed that growth opportunity turns out is not influenced by good corporate governance, since the implementation of good corporate governance is more long-term thus expected to provide benefits in the long term as well, therefore it is difficult to measure the effect in the short term.

Third, growth opportunity provides the ability to bring profits that can affect the stock return. The existence of institutional ownership as a function of monitoring in good corporate governance mechanism makes public respond negatively. At last, since good corporate governance has no significant effect on firm's growth opportunity, thus it can be concluded that the variable growth opportunity is not a suitable mediating variable between good corporate governance and stock return. Therefore, investors should pay attention to factors other than the implementation of good corporate governance in the company.

\section{FUTURE RESEARCH DIRECTION}

The challenge for future research is to increase years of research and consider examining companies that have the same character (e.g., banking, manufacturing companies, etc.) in order to obtain more accurate results and subsequent research. Another measurement on the implementation of good corporate governance, growth opportunity, and stock return is also important in order to get another insight.

\section{REFERENCES}

1. Agustina, M. V. Norpratiwi. (2007).

Analisis Korelasi Investment Opportunity Set terhadap Stock Return pada saat Pelaporan Keuangan Perusahaan. Jurnal Akuntansi dan Manajemen, 18(April), 9-22. Retrieved from http://www.e-jurnal.com/2013/12/ analisis-korelasi-investment.html

2. Amalia, Shitta. (2011). Analisis Faktor-faktor Yang mempengaruhi Kebijakan Dividend Payout Ratio. Skripsi Universitas Diponegoro Semarang. Retrieved from https:// goo.gl/9UMgUW

3. Anshori, Muslich dan Sri Iswati. (2009). Metode Penelitian Kuantitatif. Bahan Ajar. Surabaya: Airlangga University Press.

4. Bauer, Rob, Nadja Gunster dan Roger Otten. (2004). Empirical Evidence on Corporate Governance in Europe: The Effect on Stock Returns, Firm Value and Performance. The Journal of Asset Management, 5(2), 91 104. Retrieved from https://link. springer.com/article/10.1057/palgrave.jam. 2240131

5. Brigham, Eugene dan Joel F Houston. (2001). Manajemen
Keuangan II. Jakarta: Salemba Empat.

6. Brigham, Eugene dan Joel F Houston. (2006). Fundamental of Financial Management: DasarDasar Manajemen Keuangan. Edisi 10. Jakarta: Salemba Empat.

7. Corporate Governance Perception Index (CGPI). (2008). Good Corporate Governance Dalam Perspektif Manajemen Stratejik: The Indonesian Institute For Corporate Governance. Retrieved from http://journal.unair.ac.id/ download-fullpapers-kmp1631d01b3dfull.pdf

8. Darmawati, Deni, Khomsiyah dan Rika Gelar Rahayu. (2004). Hubungan Corporate Governance dan Kinerja Perusahaan. Jurnal Riset Akuntansi Indonesia, 8(6), 65-81.

9. Dumev, A., dan Kim, E. H. (2005). To Steal or not Steal Firm Attributes, Legal Enviromnent, and Valuation. Journal of Finance, 60(3), 1461-1493. http:// dx.doi.org/10.1111/j.15406261.2005.00767.x
10. Eduardus, Tandelilin. (2010). Portofolio dan Investasi Edisi Pertama. Yogyakarta: Universitas Gajah Mada.

11. Fidhayatin, S. P., dan N. H. U. Dewi. (2012). Analisis Nilai Perusahaan, Kinerja Perusahaan Dan Kesempatan Bertumbuh Perusahaan Terhadap Stock Return Pada Perusahaan Manufaktur Yang Listing di BEI. The Indonesian Accounting Review, 2(2), 203-214. Retrieved from https://journal. perbanas.ac.id/index.php/tiar/article/view/96

12. Forum for Corporate Governance in Indonesia (FCGI). (2011). About Corporate Governance. Retrieved from www.fcgi.or.id

13. Freeman, R. E., dan J. McVea. (2001). A Stakeholder Approach to Stategic Management. SSRN.

14. Hermuningsih, S. (2013). Pengaruh Profitabilitas, Growth Opportunity, Struktur Modal Terhadap Nilai Perusahaan Pada Perusahaan Publik di Indonesia. Jurnal Buletin Ekonomi Moneter dan Perbankan, 16(2), 128-148. Retrieved from http://www.journalbankindonesia. org/index.php/BEMP/article/viewFile/27/20 
15. Himmelberg, C. P., Hubbard, R. G., \& Love, I. (2002). Investor protection, ownership and the cost of capital (Working Paper, 2834). World Bank Policy Research, Washington, DC.

16. Huang, Chi-Jui. (2010). Corporate Governance, Corporate Social Responsibility, And Corporate Performance. Journal of Management \& Organization, 16, 641-645. https://doi.org/10.1017/ S1833367200001784

17. IICG (2001). Corporate Governance: Tata Kelola Perusahaan. Edisi Ketiga, Jakarta.

18. Jensen, M. C., \& Meckling W. H. (1976). Theory of the Firm: Managerial Behavior, Agency Costs and Ownership Structure. Journal of Financial Economics, 3(4), 305-360. https://doi. org/10.1016/0304-405X(76)90026$\mathrm{X}$

19. Jogiyanto, H. M. (2000). Teori Portofolio dan Analisis Investasi. Edisi Kedua. BPFE. Yogyakarta.

20. Kartini dan Tulus Arianto. (2008). Struktur Kepemilikan, Profitabilitas, Pertumbuhan Aktiva dan Ukuran Perusahaan Terhadap Struktur Modal Pada Perusahaan Manufaktur. Jurnal Keuangan dan Perbankan, 12(1), 11-21. Retrieved from http://jurnal.unmer.ac.id/index.php/jkdp/ article/view/867

21. Khanchel, Imen. (2007).

Corporate governance: measurement and determinant analysis. Managerial Auditing Journal, 22(8), 740-760. https://doi. org/10.1108/02686900710819625

22. KNKG (2006). Pedoman Umum Good Corporate Governance Indonesia.

23. Koerniadi, Hardjo. (2014). Corporate governance and the variability of stock returns. International Journal of Managerial Finance, 10(4), 494510. https://doi.org/10.1108/IJMF08-2012-0090

24. Kouwenberg, Roy et al. (2012). Corporate Governance and Stock Retrurn in Asia. https://doi.org/10 1080/14697688.2012.762603

25. Mai, Muhammad Umar. (2006). Analisis Variabel-Variabel yang Mempengaruhi Struktur Modal Pada Perusahaan-Perusahaan LQ-45 di Bursa Efek Jakarta. Ekonomika, 228-245. Politeknik Negeri, Bandung.

26. Mas`ud, Masdar. (2008). Analisis Faktor-faktor yang Mempengaruhi Struktur Modal dan Hubungannya terhadap Nilai Perusahaan. Manajemen dan Bisnis, 7(1), Maret. Retrieved from https://fbe.ubaya.ac.id/files/download/212_20120225120917.pdf

27. Maksum, Azhar. (2005). Tinjauan Atas Good Corporate Governance Di Indonesia. Artikel yang Dipresentasikan pada Pengukuan Guru Besar di Universitas Sumatera Utara pada tanggal 17 Desember 2005.

28. Narayan, Paresh Kumar. (2015). Can governance quality predict stock market return? New Globa levidence. Pasific-Basin Finance Journal, 35, 367-380. https://doi. org/10.1016/j.pacfin.2015.02.007

29. Quynh-Nhu, Do. (2009). Leverage Growth Opportunities, and Stock Price, Response to New Financing. International Journal of Business and Management, 4(9), September 2009.

30. Ross, Stephen A., dkk. (2009). Pengantar Keuangan Perusahaan. Terjemahan oleh Ali Yudah Akbar, Rafika Yuniarsih, dan Christine. Edisi Kedelapan. Jakarta: Salemba Empat.
31. Shoeyb, Rostami et al. (2016). The Effect of Corporate Governance Components on Return on Assets and Stock Return of Companies Listed in Tehran Stock Exchange. Procedia Economics and Finance, 36, 137-146. https://doi.org/10.1016/S22125671(16)30025-9

32. Sugeng, Bambang. (2010). Pengaruh Struktur Kepemilikan dan Struktur Modal terhadap Kebijakan Inisiasi Dividen di Indonesia. Jurnal Ekonomi Bisnis, 14(1), Maret. Retrieved from http://fe.um.ac.id/wp-content/ uploads/2010/01/bambang_ sugeng_6.pdf

33. Sugiyanto, Eviatiwi Kusumaningtyas. (2010). Model Peningkatan Stock Return dan Kinerja Keuangan Melalui Corporate Social Responsibility dan Good Corporate Governance Di Bursa Efefk Indonesia. Aset, 13(1). Universitas Islam Sultan Agung.

34. Sugiyono (2008). Metode Penelitian Kuantitatif Kualitatif dan R\&D. Alfabeta: Bandung.

35. Toudas, Kanellos dan Athanasios Bellas. (2014). Corporate Governance and its Effect on Firm Value and Stock Returns of Listed Companies on the Athens Stock Exchange. European Research Studies, 17(2), 58-80. Retrieved from http://www.ersj.eu/repec/ers/ papers/14_2_p5.pdf

36. Wardani, Diah Kusuma. (2008). Pengaruh Corporate Governance Terhadap Kinerja Perusahaan di Indonesia. Fakultas Ekonomi UII: Yogyakarta.

37. Webb, Elizabeth. (2006). Relationships between board structure and takeover defenses, 6(3), 268-280. 